Retraction

\title{
Retracted: The Long-Term Settlement Deformation Automatic Monitoring System for the Chinese High-Speed Railway
}

\author{
Shock and Vibration \\ Received 24 October 2018; Accepted 24 October 2018; Published 2 December 2018 \\ Copyright (c) 2018 Shock and Vibration. This is an open access article distributed under the Creative Commons Attribution \\ License, which permits unrestricted use, distribution, and reproduction in any medium, provided the original work is \\ properly cited.
}

\begin{abstract}
At the request of the authors, the article titled "The LongTerm Settlement Deformation Automatic Monitoring System for the Chinese High-Speed Railway" [1] has been retracted and blanked. The article was found to contain information provided by China Railway Design Group Co., Ltd. The authors did not acknowledge the company's role in their work. The company believes that this article infringes on their intellectual property.
\end{abstract}

\section{References}

[1] X. Wang, L. Wu, Y. Zhou, and Y. Wang, "The long-term settlement deformation automatic monitoring system for the Chinese high-speed railway," Shock and Vibration, vol. 2015, Article ID 147972, 12 pages, 2015. 